\title{
PENERAPAN PRINSIP AKUNTABILITAS \\ (ACCOUNTABILITY) DAN PRINSIP PERTANGGUNGJAWABAN (RESPONSIBILITY) GOOD CORPORATE GOVERNANCE (GCG) TERKAIT PERJANJIAN SRIWIJAYA AIR TRAVEL PASS (SJTP)
}

\author{
Ayunda Gayatri Maheswari ${ }^{-1}$, Tarsisius Murwadji, Agus Suwandono
}

Program Studi Sarjana Ilmu Hukum, Fakultas Hukum Universitas Padjadjaran

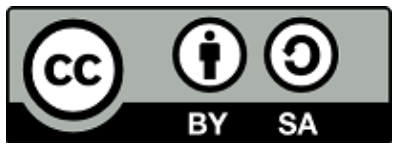

DOI: http://dx.doi.org/10.33603/hermeneutika.v3i2

Diterima: 9 November 2019; Direvisi: 11 Januari 2020; Dipublikasikan: Februari 2020

\begin{abstract}
Abstrak: Penerapan prinsip Good Corporate Governance (GCG) mengarahkan perusahaan untuk membentuk tata kelola manajemen perusahaan yang bersih, transparan, dan professional. Penerapan prinsip GCG di Indonesia masih tergolong rendah, berakibat pada munculnya salah satu kasus yaitu mengenai Sriwijaya Air Travel Pass (SJTP). Tujuan penelitian ini adalah untuk mengetahui mengenai penerapan prinsip-prinsip Good Corporate Governance (GCG) terkait Perjanjian Sriwijaya Air Travel Pass (SJTP) dan apakah penerapannya sudah sesuai dengan Undang-Undang Nomor 40 Tahun 2007 tentang Perseroan Terbatas dan pengaturan lainnya, dan menganalisis akibat hukum apabila tidak diterapkannya prinsip tersebut di PT. Sriwijaya Air. Metode penelitian yang digunakan di dalam penulisan skripsi ini adalah menggunakan metode pendekatan yuridis implementatif, yaitu metode penelitian hukum yang mencari kesesuaian fakta di lapangan dengan peraturan yang mengaturnya, dalam hal ini prinsip Good Corporate Governance (GCG) di dalam Undang-Undang Nomor 40 Tahun 2007 tentang Perseroan Terbatas yang akan menjadi dasar yuridis terkait perjanjian keanggotaan Sriwijaya Air Travel Pass (SJTP) serta peraturan perundang-undangan lainnya. Berdasarkan hasil penelitian ini, dapat disimpulkan bahwa maskapai Sriwijaya Air belum menerapkan prinsip Akuntabilitas (Accountability) dan prinsip pertanggungjawaban (Responsibility) Good Corporate Governance (GCG) di dalam peraturan internal perusahaan dan secara otomatis tidak pula diterapkan di dalam perjanjian Sriwijaya Air Travel Pass (SJTP) sehingga pihak maskapai Sriwijaya Air memiliki kewajiban untuk memberikan ganti kerugian kepada konsumen/anggota Sriwijaya Air Travel Pass (SJTP).
\end{abstract}

Kata kunci: Prinsip Akuntabilitas, Prinsip Pertanggungjawaban, Good Corporate Governance (GCG), Sriwijaya Air Travel Pass (SJTP)

\footnotetext{
${ }^{1}$ Ayunda Gayatri Maheswari

Email: ayundagmaheswari@gmail.com
} 


\section{PENDAHULUAN}

Di era persaingan global, Banyaknya perusahaan yang bangkrut karena masih buruknya standar tata kelola perusahaan dan adanya penyakit moral masyarakat berupa kecurangan (fraud) seperti masalah korupsi, kolusi, dan nepotisme (KKN) yang menyebabkan kerugian perusahaan. Perusahaanperusahaan yang dapat bertahan merupakan perusahaan yang memiliki tata kelola yang baik dan citra perusahaan yang telah dipercaya oleh masyarakat/publik. Untuk mendapatkan citra yang baik di mata masyarakat, para pelaku usaha melakukan upaya-upaya persaingan yang sehat.

Kondisi persaingan global tersebut mengakibatkan sangat dibutuhkannya sistem tata kelola perusahaan yang baik, seperti Good Corporate Governance (GCG). GCG secara singkat dapat diartikan sebagai prinsip yang mendorong terbentuknya pola kerja manajemen yang bersih, transparan dan profesional. GCG diyakini sebagai kunci sukses bagi suatu perusahaan untuk tumbuh dan berkembang serta menguntungkan dalam jangka panjang. ${ }^{2}$ Penerapan GCG di dunia didukung oleh beberapa lembaga-lembaga seperti World Bank, IMF, dan APEC, yang menyusun beberapa prinsip umum dalam GCG.

Prinsip-prinsip tersebut adalah
prinsip keadilan mensyaratkan adanya keadilan dan kesetaraan bagi seluruh pihak, kemudian adanya prinsip Keterbukaan (Transparency), yang mensyaratkan adanya keterbukaan dalam mengemukakan seluruh informasi materiil dan relevan mengenai perusahaan, kemudian terdapat prinsip Akuntabilitas (Accountability), yaitu prinsip yang mensyaratkan adanya kejelasan fungsi, pelaksanaan, dan pertanggungjawaban dari seluruh organ perusahaan, dan yang terakhir adalah prinsip Pertanggungjawaban (Responsibility), yaitu prinsip yang mensyaratkan adanya kesesuaian di dalam pengelolaan perusahaan terhadap peraturan perundang-undangan yang berlaku dan prinsip-prinsip korporasi.

Implementasi prinsip GCG dimaksudkan agar terwujudnya keterbukaan informasi, adanya pertanggungjawaban pimpinan, perlakuan adil bagi setiap karyawan dalam menjalankan kewajiban dan menerima hakhalnya sebagai karyawan maupun adanya keterlibatan dari seluruh karyawan dalam pengembangan perusahaan untuk meraih visi dan misi perusahaan. Prinsip Good Corporate Governance (GCG) adalah suatu subjek yang memiliki banyak aspek. Salah satu topik utama dalam tata kelola perusahaan adalah menyangkut masalah akuntabilitas dan tanggung jawab, khususnya implementasi pedoman dan mekanisme untuk memastikan perilaku yang baik dan melindungi kepentingan para pemegang saham. Fokus utama lain adalah efisiensi ekonomi yang menyatakan bahwa sistem tata kelola perusahaan harus ditujukan untuk mengoptimalisasi hasil ekonomi, dengan tidak hanya mempertimbangkan kepentingan para pemegang saham, namun juga kepentingan pihak ketiga.

Penerapan prinsip Good Corporate Governance (GCG) tidaklah mudah, hal ini tercermin dari kualitas GCG di Indonesia yang masih tergolong rendah. Rendahnya penerapan prinsip GCG di perusahaan mengakibatkan munculnya kasus-kasus yang menimbulkan kerugian bagi beberapa pihak. Salah satu kasusnya adalah mengenai Sriwijaya Air Travel Pass (SJTP).

Sriwijaya Air Travel Pass (SJTP) merupakan program Sriwijaya Air untuk

${ }^{2}$ Suprayitno, G dkk, Internalisasi Good Corporate Governance, IICG: Jakarta, 2005, hlm. 15. 
mengakomodir masyarakat yang sering melakukan perjalanan dengan harga yang terjangkau, dengan membayar sejumlah uang, member SJTP dapat berpergian selama 365 hari mengelilingi Indonesia dan tidak membatasi jumlah penerbangan domestik yang akan diambil. Namun, terdapat permasalahan pada saat pertengahan program tersebut berlangsung, yaitu adanya ketidak sesuaian antara ketentuan pada perjanjian awal dengan fakta di lapangan. Hal ini tentu menimbulkan banyak kerugian bagi para member SJTP, karena member SJTP tersebut telah memenuhi kewajibannya sebagai anggota member, yakni dengan membayarkan sejumlah uang pada awal perjanjian di buat, namun hak-haknya sebagai konsumen tidak dipenuhi oleh pihak maskapai Sriwijaya Air.

Berangkat dari hal tersebut, perlu ditelurusi atau diteliti mengenai penerapan prinsip-prinsip Good Corporate Governance (GCG) terkait Perjanjian Sriwijaya Air Travel Pass (SJTP), serta mengetahui akibat hukum dari tidak diterapkannya prinsip-prinsip Good Corporate Governance di PT. Sriwijaya Air.

\section{METODE PENELITIAN}

Metode Penelitian yang digunakan merupakan penelitian hukum normatif dengan menggunakan metode pendekatan yuridis implementatif, yaitu metode penelitian hukum yang mencari kesesuaian fakta di lapangan dengan peraturan yang mengaturnya, dalam hal ini adalah UndangUndang Nomor 40 Tahun 2007 tentang Perseroan Terbatas yang akan menjadi dasar yuridis dari penerapan prinsip Good Corporate Governance (GCG).

Untuk meneliti mengenai spesifikasi penelitian digunakan metode deskriptif analisis, yaitu metode penelitian dengan mencari unsur-unsur yang terdapat di dalam fakta hukum yang telah ada, kemudian penulis akan mencari unsurunsur tersebut dalam hukum dan menganalisis untuk dapat memberikan gambaran menyeluruh mengenai permasalahan yang ada. ${ }^{3}$

\section{HASIL PENELITIAN}

a. Penerapan prinsip Akuntabilitas (Accountability) dan Pertanggungjawaban (Responsibility) di dalam Good Corporate Governance (GCG) dalam upaya mewujudkan tata kelola perusahaan transportasi yang baik terkait Perjanjian Keanggotaan Sriwijaya Air Travel Pass (SJTP).

Tujuan utama dari Good Corporate Governance adalah untuk menciptakan sistem pengendalian dan keseimbangan (check\&balances) untuk mencegah penyalahgunaan dari sumberdaya perusahaan dan tetap mendorong terjadinya pertumbuhan perusahaan. Secara umum, tata kelola perusahaan adalah rangkaian proses, kebiasaan, kebijakan, aturan, dan institusi yang mempengaruhi pengarahan, pengelolaan, serta pengontrolan suatu perusahaan atau korporasi.

Prinsip Akuntabilitas dimaksudkan sebagai prinsip yang mengatur peran dan tanggung jawab manajemen agar dalam mengelola perusahaan dapat dipertanggungjawabkan serta mendukung usaha untuk menjamin penyeimbang kepentingan manajemen dan pemegang saham serta pihak ketiga, sebagaimana yang diawasi oleh dewan komisaris. ${ }^{4}$ Dewan komisaris dalam hal ini memberikan pengawasan terhadap manajemen mengenai kinerja dan pencapaian target yang telah ditetapkan bagi pemegang saham. Supaya prinsip akuntabilitas ini efektif, maka harus dijaga

${ }^{3}$ Sugiyono, Metode Penelitian Kuantitatif, Kualitatif dan $R \& D$, Bandung: Alfabeta, 2008, hlm. 105.

${ }^{4}$ Ibid, hlm. 13. 
independensinya dari pengaruh manajemen. ${ }^{5}$

Perusahaan

seharusnya

mendefinisikan fungsi, hak, dan kewajiban serta tanggung jawab masing-masing organ perusahaan serta mengomunikasikan halhal tersebut kepada setiap pihak yang berkepentingan. Setiap keputusan yang diambil oleh manajemen perusahaan seharusnya jelas aspek akuntabilitasnya. Perusahaan harus senantiasa menjaga keseimbangan antara kepentingan pemegang saham, dengan pemangku kepentingan lainnya. Perusahaan menerapkan prinsip akuntabilitas sebagai salah satu cara untuk mengatasi persoalan yang timbul akibat adanya pembagian tugas (division of authority) antar organ perusahaan serta mengurangi dampak dari agency problem yang timbul akibat perbedaan kepentingan antara manajemen, pemegang saham, dan pemangku kepentingan.

Perusahaan

memastikan pengelolaan perusahaan dengan mematuhi peraturan perundang-undangan serta ketentuan yang berlaku sebagai cermin tanggung jawab korporasi sebagai warga korporasi yang baik. Perusahaan selalu mengupayakan kemitraan dengan semua pemangku kepentingan dalam batas-batas peraturan perundang-undangan dan etika bisnis yang sehat. Jadi prinsip dasar perusahaan harus mematuhi peraturan perundang-undangan serta melaksanakan tanggung jawab terhadap masyarakat dan lingkungan sehingga dapat terpelihara kesinambungan dalam jangka Panjang dan mendapat pengakuan sebagai good coporate citizen. ${ }^{6}$ Salah satu pedoman pelaksanaan prinsip pertanggungjawaban ini adalah organ perusahaan harus berpegang teguh pada prinsip kehati-hatian dan memastikan kepatuhan terhadap

5 Muh. Arief Effendi, The Power of Good Corporate Governance: Teori dan Implementasi, Salemba Empat: Jakarta, 2018, hIm. 2. peraturan perundang-undangan, anggaran dasar dan perusahaan.

$\begin{array}{lrr}\text { Perwujudan } & \text { prinsip } & \text { Akuntabilitas } \\ \text { (Accountability) } & \text { dan } & \text { prinsip } \\ \text { pertanggungjawaban } & & \text { (responsibility) }\end{array}$
tercantum di dalam Pasal 97 UndangUndang Nomor 40 Tahun 2007 tentang Perseroan Terbatas yang pada intinya adalah direksi harus bertanggungjawab atas pengurusan perseroan dengan itikad baik dan penuh tanggung jawab, serta direksi bertanggungjawab secara pribadi atas kerugian perseroan apabila yang bersangkutan bersalah atau lalai dalam menjalankan tugasnya. Selain itu juga tercantum di dalam Pasal 114 UndangUndang Nomor 40 Tahun 2007 tentang Perseroan Terbatas yang pada intinya mengatur bahwa dewan komisaris bertanggung jawab atas pengawasan perseroan dan wajib dilakukan dengan itikad baik, kehati-hatian, dan bertanggungjawab dalam menjalankan tugas pengawasan serta ikut bertanggung jawab secara pribadi atas kerugian perseroan apabila lalai atau bersalah dalam menjalankan tugasnya.

Prinsip akuntabilitas tercantum di dalam Pasal 97 Ayat (2) yang menyatakan bahwa direksi dalam menjalankan kepengurusan Perseroan harus dilaksanakan dengan itikad baik dan penuh tanggung jawab. Karakter atau indikator 'itikad baik' dalam hal ini di antaranya adalah keadilan, kepatutan, tidak menyalahgunakan keadaan, paksaan, penipuan, kesesatan, kejujuran, dan kepatuhan. Penerapan prinsip akuntabilitas dan pertanggungjawaban harus diwujudkan ke dalam seluruh aktivitas bisnis suatu perusahaan, salah satunya harus diterapkan di peraturan internal perusahaan itu sendiri yang dijadikan pedoman atau dasar dalam mengambil setiap keputusan di perusahaan,
${ }^{6}$ Rusdiyanto, dkk, Good CorporateGovernance: Teori dan Implementasinya di Indonesia, PT Refika Aditama: Bandung, 2019, hlm. 73. 
kemudian diterapkan lagi dalam berbagai aktivitas bisnis perusahaan.

Penerapan prinsip-prinsip Good Corporate Governance (GCG), khususnya prinsip akuntabilitas (Accountability) dan prinsip pertanggungjawaban (Responsibility) dibuktikan dengan adanya pertanggungjawaban dari korporasi dalam menjalankan aktivitas bisnisnya. Berdasarkan ketentuan peraturan perundang-undangan di atas dalam menjalankan perusahaan harus didasarkan kepada asas itikad baik yang tercantum di dalam penerapan prinsip akuntabilitas (Accountability) dan prinsip pertanggungjawaban (Responsibility) agar terdapat pertanggungjawaban pengelolaan perusahaan sekaligus pengawasan dalam pembentukan produk hukum agar tidak bertentangan dengan ketentuan perundangundangan. ${ }^{7}$

Sriwijaya Air menuturkan bahwa dalam peraturan internal perusahaannya telah mengikuti ketentuan perundangundangan yaitu Undang-Undang Nomor 40 Tahun 2007, prinsip-prinsip yang digunakan dalam peraturan internal perusahaan adalah prinsip yang dibentuk oleh Perusahaan Sriwijaya Air sendiri yaitu Integrity, Customer Bonding, Adaptive and Innovative, Responsibility, Excellent, dan Synergy. Sriwijaya Air dalam menjalankan perusahaannya di tahun-tahun sebelumnya menggunakan prinsip yang telah dibentuk dan disepakati oleh seluruh jajaran di perusahaan dengan didasarkan kepada Undang-Undang Nomor 40 Tahun 2007 tentang Perseroan Terbatas. Penerapan prinsip Good Corporate Governance (GCG) ke dalam peraturan internal perusahaan dan seluruh aktivitas bisnis perusahaan baru direncanakan dan telah dibentuk di tahun 2019.

Perusahaan Sriwijaya Air menyatakan telah membentuk 3 (tiga) pedoman dalam menjalankan perusahaannya, yaitu Code of Corporate yaitu pedoman kebijakan pelaksanaan tata kelola perusahaan, kemudian Board of Manual yaitu pedoman bagi jajaran direksi dalam menjalankan tugas dan kewajibannya, dan yang terakhir adalah Code of Conduct, yaitu pedoman perilaku kerja bagi insan Sriwijaya Air dalam melaksanakan kegiatan usaha perusahaan dengan pihak pemangku kepentingan. Ketiga pedoman tersebut dijadikan landasan dalam mengimplementasikan tata kelola perusahaan yang baik. Tata kelola perusahaan Sriwijaya Air dilandaskan kepada standar terbaik sesuai dengan Undang-Undang Nomor 40 Tahun 2007 tentang Perseroan Terbatas dan UndangUndang Nomor 1 Tahun 2009 tentang Penerbangan. Namun, implementasi prinsip Good Corporate Governance (GCG) ke dalam ketiga pedoman tersebut belum disahkan oleh pemegang saham sehingga belum diterapkan dan dijalankan karena perusahaan Sriwijaya Air mengalami perombakan besar-besaran yakni perubahan jajaran direksi dan juga perbaikan seluruh sistem perusahaan yang mengakibatkan pengesahan pedomanpedoman tersebut menjadi tertunda dan terhambat.

Prinsip-prinsip tersebut tidak hanya wajib diterapkan di dalam peraturan internal perusahaan, tetapi juga harus diterapkan di seluruh produk hukum perusahaan. Dalam hal ini penulis membahas salah satu produk hukum Perusahaan Sriwijaya Air, yaitu perjanjian di dalam program Sriwijaya Air Travel Pass (SJTP). Di dalam perjanjian Sriwijaya Air Travel Pass (SJTP) terdapat beberapa ketentuan mengenai program SJTP tersebut, yaitu seperti definisi, tujuan, kondisi, cara pembayaran, dan jangka waktu program tersebut. Namun, terdapat

7 Muhammad Shidqon, Dasar-Dasar Good Corporate Governance, UII Press Yogyakarta: Yogyakarta, 2018, hlm. 27. 
beberapa ketentuan di dalam perjanjian tersebut yang tidak mencerminkan asas itikad baik dalam prinsip akuntabilitas (Accountability) dan prinsip pertanggungjawaban (Responsibility) yaitu ketentuan mengenai perubahan ketentuan secara sepihak yang dapat dilakukan oleh pihak maskapai, kemudian adanya ketidaksesuaian antara perjanjian dengan fakta di lapangan yaitu mengenai pembatasan atau kuota dalam penerbangan, kemudian pihak maskapai yang berhak membatalkan tiket penerbangan member secara sepihak tanpa konfirmasi. Penulis mendapatkan beberapa informasi terkait program tersebut dari salah satu member SJTP yang juga merasa dirugikan sebagai akibat dari perubahan-perubahan ketentuan secara sepihak yang dilakukan pihak maskapai. Ketentuan yang pada awalnya tidak ada, dan baru muncul di tengahtengah periode program tanpa kesepakatan kedua belah pihak.

Ketentuan-ketentuan tersebut bertentangan dengan ketentuan perundangundangan. Di dalam indikator itikad baik terdapat kejujuran dan kepatuhan dalam pelaksanaan perjanjian. Pada awal program Sriwijaya Air Travel pass (SJTP) tersebut dibentuk, terdapat ketentuan dalam perjanjian antara kedua belah pihak yang pada intinya menyatakan bahwa tidak terdapat batasan apapun dalam pembelian tiket bagi member SJTP kecuali penerbangan charter dan extra flight. Namun, pada fakta di lapangan, terdapat ketentuan-ketentuan di dalam perjanjian yang secara sepihak diubah oleh pihak Sriwijaya Air tanpa meminta persetujuan pihak member. Seharusnya dalam pelaksanaan perjanjian, apabila terdapat perubahan ketentuan-ketentuan dalam perjanjian, hal tersebut harus dengan persetujuan kedua belah pihak.

Perubahan ketentuan-ketentuan dalam perjanjian tersebut disampaikan oleh pihak Sriwijaya Air melalui e-mail, yang pada intinya berisi mengenai pembatasan pada beberapa penerbangan, yang tidak memberikan celah kepada member untuk memberikan penolakan ataupun persetujuan mengenai perubahan ketentuan tersebut. Perubahan ketentuan tersebut tentu merugikan member Sriwijaya Air Travel Pass (SJTP). Hal ini juga membuktikan bahwa Sriwijaya Air tidak jujur dan patuh dalam pelaksanaan perjanjian program Sriwijaya Air Travel Pass (SJTP), juga tidak melaksanakan program berdasarkan itikad baik. Berdasarkan prinsip akuntabilitas, segala aktivitas bisnis yang dilakukan korporasi harus dengan itikad baik dan dapat dipertanggungjawabkan.

Perjanjian Sriwijaya Air Travel Pass berbentuk seperti aplikasi, yang apabila member sudah menyetujui terms and conditions nya maka dapat langsung menggunakan aplikasi tersebut untuk membeli tiket penerbangan, check-in, manage booking, dan aktivitas lain yang berhubungan dengan penerbangan mereka. Di dalam perjanjian tersebut, terdapat informasi-informasi mengenai produk Sriwijaya Air Travel Pass (SJTP), seperti tujuan pembentukan program, definisi program, kemudian terdapat poin-poin mengenai ketentuan dan kondisi yang berisikan tata cara pendaftaran member, metode pembayaran, dan penjelasan mengenai Sriwijaya Mobile Apps. Kemudian terdapat juga penjelasan mengenai kondisi tiket, pembatalan membership, dan juga benefit bagi member Sriwijaya Air Travel Pass (SJTP).

Dalam membentuk perjanjian, terdapat asas kebebasan berkontrak, yakni para pihak bebas dalam menentukan muatan perjanjian maupun bentuk perjanjiannya. Namun, asas kebebasan berkontrak ini dibatasi, karena kebebasan tersebut tidak boleh bertentangan dengan peraturan perundang-undangan manapun. Mengenai sah atau tidaknya suatu perjanjian dapat merujuk kepada Pasal 1320 BW mengenai syarat sahnya perjanjian yaitu sepakat mereka yang mengikatkan dirinya, cakap untuk membuat suatu perjanjian, suatu hal tertentu, dan suatu sebab yang halal. Maka 
untuk menilai sah atau tidaknya perjanjian Sriwijaya Air Travel Pass, dapat merujuk kepada ketentuan pasal tersebut.

Sepakat mereka yang mengikatkan dirinya mengandung makna bahwa para pihak yang membuat perjanjian telah sepakat atau ada persesuaian kemauan atau saling menyetujui kehendak masingmasing pihak dengan tidak ada paksaan, kekeliruan, dan penipuan. Dalam hal ini para pihak dalam perjanjian tersebut adalah Sriwijaya Air dan calon member Sriwijaya Air Travel Pass (SJTP). Berdasarkan keterangan beberapa member, mereka telah sepakat untuk melaksanakan perjanjian dengan berdasarkan kemauan dan kehendak sendiri tanpa adanya paksaan dari pihak manapun. Maka dapat dikatakan bahwa unsur ini telah terpenuhi.

Cakap untuk membuat suatu perjanjian merupakan syarat umum untuk dapat melakukan perbuatan hukum yang sah, yaitu telah dewasa, sehat akal dan pikiran, dan tidak dilarang oleh suatu peraturan perundang-undangan untuk melakukan suatu perbuatan tertentu. Dalam hal ini para pihak telah cakap hukum karena telah dewasa, sehat akal dan pikiran, serta tidak dilarang oleh suatu peraturan perundang-undangan. Suatu hal tertentu di dalam perjanjian adalah objek suatu perjanjian harus tertentu, dalam hal ini objek perjanjiannya adalah Sriwijaya Air Travel Pass (SJTP), maka unsur tersebut juga telah terpenuhi.

Suatu sebab yang halal adalah bahwa isi dan jenis perjanjian tersebut tidak bertentangan dengan undang-undang manapun, kesusilaan, dan ketertiban umum. Dalam hal ini, terdapat beberapa ketentuan di dalam perjanjian Sriwijaya Air Travel Pass yang bertentangan dengan beberapa peraturan perundang-undangan. Adanya klausa pembatalan sepihak yang dapat dilakukan oleh pihak Sriwijaya Air, yaitu pembatalan tiket penerbangan tanpa adanya konfirmasi kepada pihak member. Hal ini bertentangan dengan Pasal 1338 BW yang pada intinya mengatur bahwa suatu persetujuan tidak dapat ditarik kembali selain dengan kesepakatan kedua belah pihak, atau karena alasan-alasan yang ditentukan oleh undang-undang, persetujuan harus dilaksanakan dengan itikad baik. Dalam hal ini pihak Sriwijaya Air telah menarik beberapa ketentuan dalam perjanjian tanpa kesepakatan oleh para pihak, bahkan pembatalan tiket penerbangan secara sepihak dilakukan pihak Sriwijaya Air tanpa pemberitahuan ataupun konfirmasi kepada para pihak.

Perubahan ketentuan secara sepihak ini termasuk ke dalam penyalahgunaan keadaan yaitu merupakan perbuatan yang dilatarbelakangi oleh keadaan tidak seimbang antara para pihak. pihak yang lemah tidak memiliki kesempatan untuk mendiskusikan segala sesuatu yang menjadi hak dan kewajibannya dalam sebuah perjanjian. Pihak Sriwijaya Air tidak memberikan celah ataupun kesempatan kepada member untuk dapat menyetujui ataupun sekedar mendiskusikan perihal pembatalan tersebut, hal ini tentu merugikan pihak member sebagai pihak yang lemah di dalam perjanjian Sriwijaya Air Travel Pass (SJTP).

Perjanjian Sriwijaya Air Travel Pass (SJTP) terbukti bertentangan dengan peraturan perundang-undangan yaitu Pasal 1338 BW. Suatu sebab yang halal merupakan salah satu syarat objektif dalam perjanjian karena mengenai objek perjanjian, apabila syarat objektif tersebut tidak terpenuhi maka perjanjian tersebut batal demi hukum. Artinya dari semula tidak pernah dilahirkan suatu perjanjian dan tidak pernah ada perikatan. Dalam hal tidak terpenuhinya syarat objektif maka dapat dikembalikan keadaan seperti sediakala, dalam hal ini pengembalian uang muka yang telah dibayarkan member pada awal perjanjian dibuat. Mengenai jumlah pengembalian maka dapat didiskusikan oleh kedua belah pihak.

Penerapan prinsip Good Corporate Governance (GCG) merupakan standar atau pedoman dalam tata kelola perusahaan 
untuk mendorong peningkatan akuntabilitas, keadilan, transparansi, dan tanggung jawab. Penerapan prinsip GCG tersebut juga bertujuan untuk mendorong kinerja sumber-sumber perusahaan untuk berfungsi secara efisien guna menghasilkan nilai ekonomi jangka panjang. Nilai ekonomi jangka panjang yang menguntungkan tidak dapat dicapai apabila perusahaan hanya mengikuti standar pengelolaan perusahaan. Dalam upaya untuk mencapai tingkat kepuasan tinggi dari konsumen, maka perusahaan dalam menjalankan aktivitas bisnisnya harus dapat melampaui standar yang telah ditentukan. Hal ini telah tercantum di dalam ilmu mutu. Terdapat 3 (tiga) tingkatan dalam kepuasan konsumen menurut ilmu mutu, yaitu kepuasan dasar, menengah, dan tinggi.

$$
\text { Prinsip Good Corporate }
$$

Governance (GCG) merupakan standar dalam tata kelola perusahaan, yang apabila diterapkan dan dipenuhi maka konsumen hanya akan mencapai kepuasan dasar, yakni kepuasan yang sesuai dengan harapan konsumen. Perusahaan sebagai pelaku bisnis, sekurang-kurangnya harus mencapai standar, yakni dengan menerapkan dan melaksanakan prinsip Good Corporate Governance (GCG).

Berdasarkan teori ilmu mutu tersebut, maka apabila suatu perusahaan ingin mencapai nilai ekonomi jangka panjang yang menguntungkan, maka perusahaan seharusnya tidak hanya memenuhi standar kepuasan konsumen, melainkan harus melampau ekspektasi konsumen sehingga kepuasan konsumen akan berada di tingkat kepuasan yang tinggi. Dalam hal ini maskapai Sriwijaya Air seharusnya melampaui standar yang ada di dalam prinsip Good Corporate Governance (GCG). Tingkat kepuasan konsumen yang tinggi dan konsisten akan mewujudkan nilai ekonomi jangka panjang yang menguntungkan bagi perusahaan, dan bagi konsumen itu sendiri.

\section{b. Akibat Hukum Tidak Diterapkannya Prinsip Akuntabilitas (Accountability) dan Prinsip Pertanggungjawaban (Responsibility) Good Corporate Governance (GCG)}

Berdasarkan keterangan dari narasumber selaku member Sriwijaya Air Travel Pass (SJTP) pihak Sriwijaya Air pada awalnya mengubah ketentuan mengenai check-in, yang semula dapat dilakukan via web menjadi tidak bisa. Kemudian muncul beberapa perubahan ketentuan secara sepihak kembali yakni mengenai pembatasan atau kuota pada beberapa penerbangan pada saat perubahan ketentuan mengenai pembatasan atau kuota pada beberapa penerbangan, dan adanya sistem stand by yakni apabila penerbangan telah full booked maka member dapat membeli tiket dan datang ke bandar udara namun dengan sistem waiting list. Dengan adanya ketidakjelasan tersebut, pihak member telah berusaha menghubungi pihak Sriwijaya Air untuk meminta konfirmasi dan pertanggungjawaban atas kerugiankerugian yang ditimbulkan akibat dari perubahan ketentuan tersebut.

$$
\text { Keluhan-keluhan dari pihak }
$$
member tidak ditanggapi, bahkan pihak member juga telah membuat petisi yang telah ditandatangani oleh ribuan member lainnya yang intinya berisikan tentang permintaan pertanggungjawaban dari pihak maskapai. Pihak member juga telah mendatangi langsung kantor Sriwijaya Air, namun mereka (Sriwijaya Air) hanya menerima keluh kesah member dan menjawab bahwa hal tersebut akan disampaikan ke pihak manajemen. Karena tidak pernah mendapatkan tanggapan dari pihak manajemen, ribuan member Sriwijaya Air Travel Pass (SJTP) yang diwakili oleh beberapa orang memutuskan untuk membawa kasus tersebut ke Yayasan Lembaga Konsumen Indonesia (YLKI) di Jakarta Selatan. Pihak YLKI melakukan mediasi antara member dengan pihak Sriwijaya Air yang diwakili oleh pihak manajemen, mediasi tersebut berisi tuntutan-tuntutan ganti rugi yang 
dilayangkan pihak member kepada pihak maskapai, dapat berupa pengembalian sebagian uang ataupun perpanjangan masa membership dengan pengembalian ketentuan lama sesuai dengan yang telah diperjanjikan.

Direksi sebagai pihak yang bertanggungjawab dalam pengurusan perseroan mempunyai kewajiban untuk menerapkan prinsip Good Corporate Governance (GCG) dalam perusahaan. Dalam menjalankan tugas-tugas tersebut, direksi diwajibkan untuk beritikad baik dan penuh tanggung jawab. Tidak diterapkannya prinsip Good Corporate Governance (GCG) ke dalam peraturan internal perusahaan ataupun aktivitas bisnis perusahaan oleh Direksi yang mengakibatkan kerugian, maka dapat dikatakan bahwa Direksi dalam hal ini melanggar fiduciary duties yang tercantum di dalam Pasal 97 Ayat (2) Undang Undang Nomor 40 Tahun 2007 tentang Perseroan Terbatas.

Pelanggaran terhadap Pasal 97 Ayat (2) Undang-Undang Nomor 40 Tahun 2007 tentang Perseroan Terbatas, maka sesuai dengan ketentuan Pasal 97 Ayat (3) Undang-Undang Nomor 40 Tahun 2007, setiap anggota direksi bertanggungjawab penuh secara pribadi atas kerugian perseroan karena telah bersalah atau lalai dalam menjalankan tugasnya sesuai dengan ketentuan sebagaimana dimaksud di dalam Ayat (2). Maka dalam kasus ini, tuntutan kerugian yang dilayangkan oleh pihak ketiga, dalam hal ini adalah member Sriwijaya Air Travel Pass (SJTP), wajib dipenuhi oleh anggota Direksi secara pribadi dan tanggung renteng.

\section{KESIMPULAN}

Berdasarkan dari hasil penelitian maka dapat disimpulkan bahwa penerapan Prinsip Akuntabilitas (Accountability) dan Prinsip Pertanggungjawaban (Responsibility) di dalam Good Corporate Governance (GCG) Terkait Perjanjian Keanggotaan Sriwijaya Air Travel Pass
(SJTP) di perusahaan Sriwijaya Air belum dilaksanakan atau belum terwujud. Terbukti dengan baru dibentuknya pedoman berdasarkan Good Corporate Governance (GCG) pada tahun 2019 lalu dan belum disahkannya pedoman tersebut serta terdapatnya ketentuan-ketentuan di dalam perjanjian Sriwijaya Air Travel Pass (SJTP) yang bertentangan dengan prinsip Akuntabilitas (Accountability) dan prinsip Pertanggungjawaban (Responsibility) Good Corporate Governance (GCG) yang tertuang dan tercantum di dalam UndangUndang Nomor 40 Tahun 2007 tentang Perseroan Terbatas.

Bentuk pertanggung jawaban pihak Maskapai Sriwijaya Air terhadap kasus tersebut dalam hal adanya pelanggaran terhadap peraturan atau prinsip dalam Good Corporate Governance (GCG) adalah Direksi sebagai pihak yang bertanggungjawab dalam pengurusan perseroan mempunyai kewajiban untuk menerapkan prinsip Good Corporate Governance (GCG) dalam perusahaan. Tidak diterapkannya prinsip Good Corporate Governance (GCG) ke dalam peraturan internal perusahaan ataupun aktivitas bisnis perusahaan oleh Direksi yang mengakibatkan kerugian, maka dapat dikatakan bahwa Direksi dalam hal ini melanggar fiduciary duties yang tercantum di dalam Pasal 97 Ayat (2) Undang Undang Nomor 40 Tahun 2007 tentang Perseroan Terbatas. Maka setiap anggota Direksi bertanggungjawab penuh secara pribadi atas kerugian perseroan karena telah bersalah atau lalai dalam menjalankan tugasnya sesuai dengan ketentuan Pasal 97 Ayat (3) Undang-Undang Nomor 40 Tahun 2007 tentang Perseroan Terbatas.

\section{DAFTAR PUSTAKA}

Muh. Arief Effendi, 2018, The Power of Good Corporate Governance: Teori dan Implementasi, Salemba Empat. 
p-ISSN 2337-6368 | e-ISSN 2615-4439

http://jurnal.unswagati.ac.id/index.php/HERMENEUTIKA

Muhammad Shidqon, 2018, Dasar-Dasar Good Corporate Governance, UII Press Yogyakarta.

Rusdiyanto, dkk, 2019, Good Corporate

Governance: Teori dan Implementasinya di Indonesia, PT Refika Aditama.

Suprayitno, G dkk, 2005, Internalisasi Good Corporate Governance, IICG.

Sugiyono, 2008, Metode Penelitian

Kuantitatif, Kualitatif dam $R \& D$

Alfabet 